\title{
Effects of sheep grazing on a spotted knapweed- infested Idaho fescue community
}

\author{
BRET E. OLSON, ROSEANN T. WALLANDER, AND JOHN R. LACEY
}

Authors are associate professor, research associate, and former range management extension specialist, Department of Animal and Range Sciences, Montana State University, Bozeman, Mont. 59717. J.R. Lacey's current address is P.O. Box 534, Glasgow, Mont. 59230.

\begin{abstract}
Spotted knapweed (Centaurea maculosa Lam.), a Eurasian perennial forb, is replacing many native perennial grasses, such as Idaho fescue (Festuca idahoensis Elmer.), in foothills of the Northern Rocky Mountain region. Our objective was to determine if 3 summers of repeated sheep grazing would reduce spotted knapweed without impacting the dominant, associated native perennial grass. Each summer, small pastures were grazed for 1-7 days in mid-June, mid-July, and early September. Areas repeatedly grazed by sheep had lower densities of seedlings, rosettes, and mature spotted knapweed plants than ungrazed areas. In addition, the proportion of young plants in the population was less in grazed than ungrazed areas. Basal areas of spotted knapweed plants were greater in grazed $\left(8.2 \mathrm{~cm}^{2}\right)$ than ungrazed areas $\left(4.0 \mathrm{~cm}^{2}\right)$. There were fewer spotted knapweed seeds in soil samples from grazed areas $\left(12\right.$ seeds $\left.\mathrm{m}^{-2}\right)$ than from ungrazed (49 seeds $\mathrm{m}^{-2}$ ). Idaho fescue plant density increased $40 \%$ in grazed areas from 1991 to 1994, but leaves and flower stems on these plants were $38 \%$ and $17 \%$ shorter, respectively, than in ungrazed areas. By 1994, frequency of Kentucky bluegrass (Poa pratensis L.) was $35 \%$ greater in grazed than ungrazed areas. Grazing did not alter the amount of litter; however the amount of bare soil increased from 2.2 to $5.6 \%$ in grazed areas, while it decreased from 4 to $1 \%$ in ungrazed areas. Three summers of repeated sheep grazing negatively impacted spotted knapweed, but minimally affected the native grass community. A long term commitment to repeated sheep grazing may slow the rate of increase of spotted knapweed in native plant communities.
\end{abstract}

Key Words: weeds, sheep, Centaurea maculosa, Festuca idahoensis, age class distribution, seed bank

Spotted knapweed (Centaurea maculosa Lam.), an aggressive, introduced perennial forb, has replaced native perennial grasses, including Idaho fescue (Festuca idahoensis Elmer.), in many foothill rangelands in the Northern Rocky Mountain region (Tyser and Key 1988, Lacey et al. 1992). Herbicides, insects, pathogens, and fire have not effectively contained the spread of this noxious weed. Large herbivores rarely graze spotted knap-

We thank P.K. Fay, P.B. Hook, K.M. Olson-Rutz and R. Sheley for reviewing the manuscript. This study was supported by the Montana Department of Agriculture (Noxious Weed Trust Fund MDA 91-13a, MDA 94-54) and the Montana Agricultural Experiment Station. This is published with approval of the Director of the Montana Agricultural Experiment Station, Journal Series J-4059. Manuscript accepted 16 Jul. 1996. weed, possibly because it contains cnicin, a bitter tasting compound (Watson and Renny 1974, Kelsey and Locken 1987).

Livestock producers have observed sheep using spotted knapweed (Cox 1989), however its tolerance to grazing is unknown. In a greenhouse study, a single defoliation did not affect spotted knapweed, whereas defoliations repeated at monthly intervals reduced root and crown weights, and carbohydrate concentrations in roots, crowns, and stems (Kennett et al. 1992, Lacey et al. 1994). Our intent was to graze the pastures repeatedly with sheep during summer dormancy when the impact on cool-season perennial grasses would be minimal. The purpose of this study was to assess the effects of repeated grazing by sheep on spotted knapweed and associated plants to determine if sheep grazing could be used to reduce the importance of this weed in a native plant community.

\section{Methods and Materials}

The study site was $14 \mathrm{~km}$ south of Bozeman, Mont. $\left(111^{\circ} 4^{\prime}\right.$ $45^{\circ} 36^{\prime}$ ) at an elevation of $1,570 \mathrm{~m}$. Soils were shallow to moderately deep, silty clay loam over sand and gravel Typic Argiboroll class, Beaverton series on an alluvial fan (USDA 1995). The 30year precipitation average for the nearest weather station (Bozeman, Mont.) was $487 \mathrm{~mm}$. Precipitation for 1991-1993 was 99,115 , and $123 \%$ of the 30 -year average, respectively. The summer (June-August) of 1991 was drier and warmer than the 30year average, whereas the summers of 1992 and especially 1993 were cooler and wetter than the long term average (Table 1). Standing crop of the vegetation in mid-June 1991 averaged 1,580 $\mathrm{kg} \mathrm{ha}^{-1}$, dominated by spotted knapweed $(25 \%)$ and Idaho fescue (41\%). Other common species at the site were arrowleaf balsamroot (Balsamorhiza sagittata (Pursh) Nutt.), Kentucky bluegrass (Poa pratensis L.), lupine (Lupinus sericeus Pursh), bluebunch wheatgrass (Pseudoroegneria spicata (Pursh) Love), and sticky geranium (Geranium viscosissimum F. \& M.).

Electronet $^{R}$ fencing enclosed three 0.1-ha pastures located randomly within a 3-ha pasture. This pasture was grazed heavily by horses before the study; there was no grazing in or near our small pastures during the study. Four $10-\mathrm{m}$ permanent transects were established inside and outside each pasture. Along each transect, $0.5-\mathrm{m}^{2}$ permanent plots were established at $1-\mathrm{m}$ intervals. Before grazing in 1991, densities of spotted knapweed (seedlings and mature plants), Idaho fescue, and arrowleaf balsamroot plants were determined, and frequency of Kentucky bluegrass was noted. Cover of bare ground and litter was estimated in these 
Table 1. Thirty-year averages and 1991-1993 mean temperatures and total precipitation for May through August, Bozeman, Mont.

\begin{tabular}{|c|c|c|c|c|c|c|c|c|}
\hline \multirow[b]{2}{*}{ Month } & \multicolumn{5}{|c|}{ Temperature } & \multicolumn{3}{|c|}{ Precipitation } \\
\hline & $\begin{array}{l}\text { 30-year } \\
\text { average }\end{array}$ & 1991 & 1992 & 1993 & 30-year average & 1991 & 1992 & 1993 \\
\hline & $\cdots \cdots$ & $\cdots$ & $\ldots$ & $\cdots$ & $\cdots \cdots$ & $\cdots$ & $\cdots$ & $\cdots$ \\
\hline Jun & 15.6 & 15.0 & 16.8 & 14.2 & 73 & 48 & 140 & 108 \\
\hline Jul & 19.6 & 20.6 & 16.9 & 14.7 & 34 & 13 & 43 & 125 \\
\hline Aug & 18.8 & 21.4 & 17.9 & 16.0 & 38 & 12 & 23 & 73 \\
\hline
\end{tabular}

plots. In the summers of 1991-1993, each pasture was grazed by 5 Targhee yearling ewes, which had never been exposed to spotted knapweed. Each pasture was grazed for 5 to 7 days in midJune, 2 to 6 days in July, and 1 to 2 days in early September depending on available forage each year. Utilization of permanently marked plants of spotted knapweed and Idaho fescue was usually high, ranging from 75 to $95 \%$ based on grazed plant frequency (Olson et al., unpublished data). Utilization based on volume removed was less than based on frequency (Olson et al. unpublished data; Pechanac 1936). Flowering stems of spotted knapweed were counted along grazed and ungrazed transects each September following grazing.

Density and frequency measures were repeated before grazing in June 1992 and 1993, and in June 1994, 9 months after grazing ceased in September 1993. In 1991 and 1992, spotted knapweed rosettes were included in the mature plant category; in 1993 and 1994 they were counted as rosettes. Basal areas, numbers of flower stems, numbers of stems (tillers), leaf heights, and flowerstem heights of spotted knapweed and Idaho fescue plants were also measured in 1994. Leaf heights and flower-stem heights were the same for spotted knapweed because of its pattern of bolting.

Samples of soil seed banks were collected in the summers of 1991 and 1994 by removing $191 \mathrm{~cm}^{3}$ of soil with a tulip bulb corer (5.7 cm dia.) placed $7.5 \mathrm{~cm}$ deep in the soil. In 1991, 10 samples were extracted from adjacent grazed and ungrazed areas in each pasture ( $n=30$ per treatment). From this baseline seed bank sample, we estimated a density of 26 viable seeds $\mathrm{m}^{-2}$. In 1994, 20 samples were extracted from adjacent grazed and ungrazed areas in each pasture ( $n=60$ per treatment). Seed bank samples were air-dried, weighed, washed through sieves to remove fine materials, and then floated to separate large sand grains. The remaining material was dried at $37^{\circ} \mathrm{C}$ for 48 hours and examined for spotted knapweed seed. Recovered seeds were tested for germination by maintaining them on moist blotter paper in petri dishes placed in a covered box in a greenhouse with $21^{\circ} \mathrm{C}$ daytime $-13^{\circ} \mathrm{C}$ nighttime temperatures. Germinated seeds were counted and removed every 2 days for 14 days. Seeds not germinating within 14 days were tested for viability with tetrazolium (AOSA 1970).

Age-class distributions of spotted knapweed populations in previously grazed and ungrazed areas were determined in the summer of 1994. Inside each pasture, 3 parallel 17-m transects were placed $5 \mathrm{~m}$ apart. The nearest spotted knapweed plant at $0.5-\mathrm{m}$ intervals along each transect was excavated, dried, and then aged by counting growth rings at 3 breaks in the upper $5 \mathrm{~cm}$ of the root (W. Good, pers. comm.). Rings were counted at 3 breaks to account for false or incomplete rings at a certain point along a root. Spotted knapweed plants, located systematically outside each pasture, were sampled similarly as those inside ( $\mathrm{n}=$ 100-106 plants in each grazed and ungrazed area). Twenty three percent of the older plants ( $\geq 3$-years-old) had rotten centers, thus their ages represent conservative estimates.

Data for variables measured all 4 years were analyzed with repeated measures analysis of variance as a randomized-complete-block design ( $n=3$; GLM, SAS 1988). Year, and the year by treatment (grazed, ungrazed) interaction for repeated measures were assessed as within subject effects. For parameters measured in 1994 only (vigor, seed banks, etc.), analysis of variance as a randomized-complete-block design was used with treatment (grazed, ungrazed) as the main effect. Each plant species was analyzed separately. Residuals from analyses of variance were normally distributed. Age class distributions of spotted knapweed from grazed and ungrazed areas were compared with a KruskalWallis nonparametric test (NPAR1WAY, SAS 1988). Age class distributions of spotted knapweed by pasture were analyzed initially to determine if there was a pasture by treatment interaction. Age class distributions of grazed and ungrazed areas were similar among the 3 pastures, so data were combined for analysis. Because of inherent variability in field studies such as this one, $P$ values less than 0.15 are presented (Gill 1981).

\section{Results}

\section{Community Response}

In grazed and ungrazed areas, density of spotted knapweed seedlings was much lower in 1992 than in 1991(Fig. 1). Seedling density in grazed areas remained low through 1994. In ungrazed areas, density was greater in 1994 than in 1992 and 1993 (year by treatment interaction, $\mathrm{P}<0.07$ ). Density of spotted knapweed rosettes was less in grazed than ungrazed areas when rosette density was first determined in 1993. Rosette density was unchanged in grazed areas; in ungrazed areas, it was greater in 1994 than 1993 (year by treatment interaction, $P<0.07$ ). Similarly, mature spotted knapweed plant densities in grazed areas were unchanged. In ungrazed areas, mature plant density in 1991 was less than in subsequent years of the study (year by treatment interaction, $\mathrm{P}<0.002$ ).

In grazed areas, density of Idaho fescue increased from 1991 to 1992 and then remained constant (Fig. 2). Idaho fescue density in ungrazed areas was unchanged from 1991 to 1994 (year by treatment interaction, $P<0.002$ ). In grazed areas, Kentucky bluegrass presence was greater in 1994 than in 1991; in ungrazed areas its presence was unchanged from 1991 to 1994 (Fig. 2, year by treatment interaction, $P<0.09$ ). Density of arrowleaf balsamroot was 

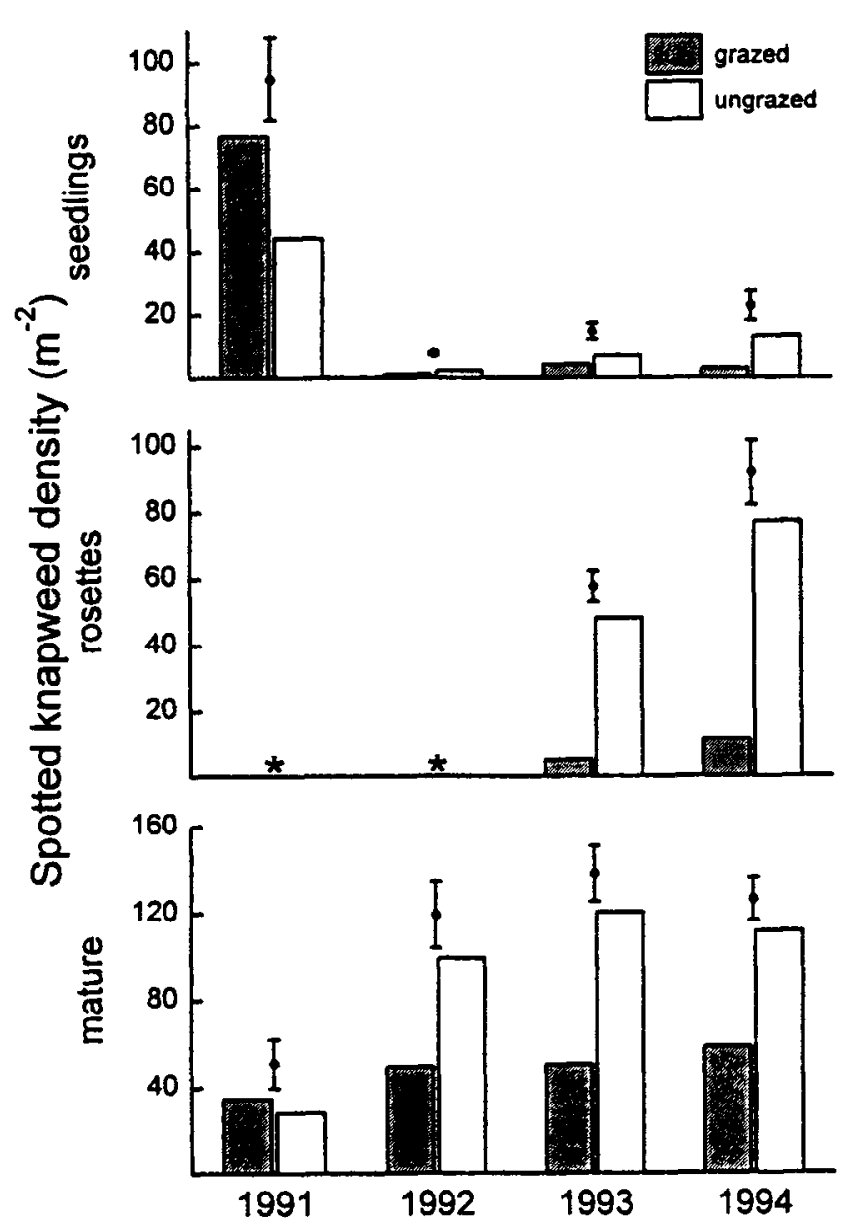

Fig. 1. Densities of spotted knapweed seedlings, rosettes, and mature plants from 1991-1994 in grazed and ungrazed areas. Densities in 1991 were determined before the sheep first grazed the pastures. Densities in 1994 were those determined after 3 years of sheep grazing. Rosettes were counted with mature plants in 1991 and 1992, and are indicated by the asterisks. Frror bars represent \pm 1 S.E.

not affected by grazing (year by treatment interaction, $P=0.22$ ), varying from 7 to $8 \%$ frequency in grazed areas and 12 to $15 \%$ in ungrazed areas from 1991 to 1994.

The proportion of bare soil increased with grazing; it decreased without grazing (Fig. 3, year by treatment interaction, $P<0.03$ ). Grazing reduced litter cover slightly (Fig. 3, grazing effect, $P<0.08$ ). Litter cover varied depending on the year (year effect, $\mathrm{P}<0.05$ ).

\section{Population Response}

More viable spotted knapweed seeds were recovered from seed bank cores taken from ungrazed areas than grazed areas $\left(49 \mathrm{~m}^{-2} \pm\right.$ 16.5 S.E. versus $12 \mathrm{~m}^{-2} \pm 10.5$ S.E., $\mathrm{P}<0.04$ ). Mean age of spotted knapweed plants was greater in grazed than ungrazed areas (3.8 versus 2.9 years, $P<0.0001$ ). In ungrazed areas, over $75 \%$ of the plants were younger than 4 years of age. In grazed areas, only $43 \%$ were younger than 4 years of age (Fig. 4). The modal age in grazed areas was 4 , whereas the modal age in ungrazed areas was 2.

After grazing in September 1991, there were fewer spotted knapweed flower stems in grazed than in ungrazed areas (Fig. 5, $\mathrm{P}<0.03$ ).
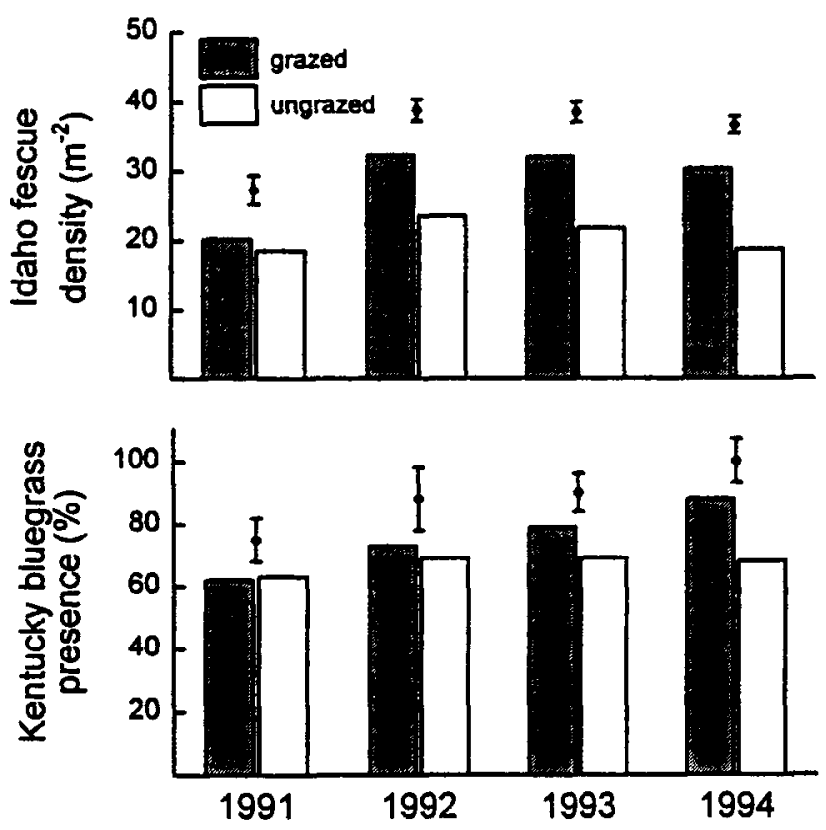

Fig. 2. Density of Idaho fescue plants and frequency of Kentucky bluegrass from 1991-1994 in grazed and ungrazed areas. Error bars represent \pm 1 S.E.

In September 1992 and 1993, the number of flower stems were similar in grazed and ungrazed areas $(P=0.33, P=0.42$, respectively). In 1994, almost 1 year after grazing ceased, grazed areas had nearly twice as many spotted knapweed flower stems as ungrazed areas $(\mathrm{P}<0.05)$.

\section{Individual Response}

Leaf and flower stem heights of spotted knapweed were similar in grazed and ungrazed areas (Table 2). Grazed plants had more
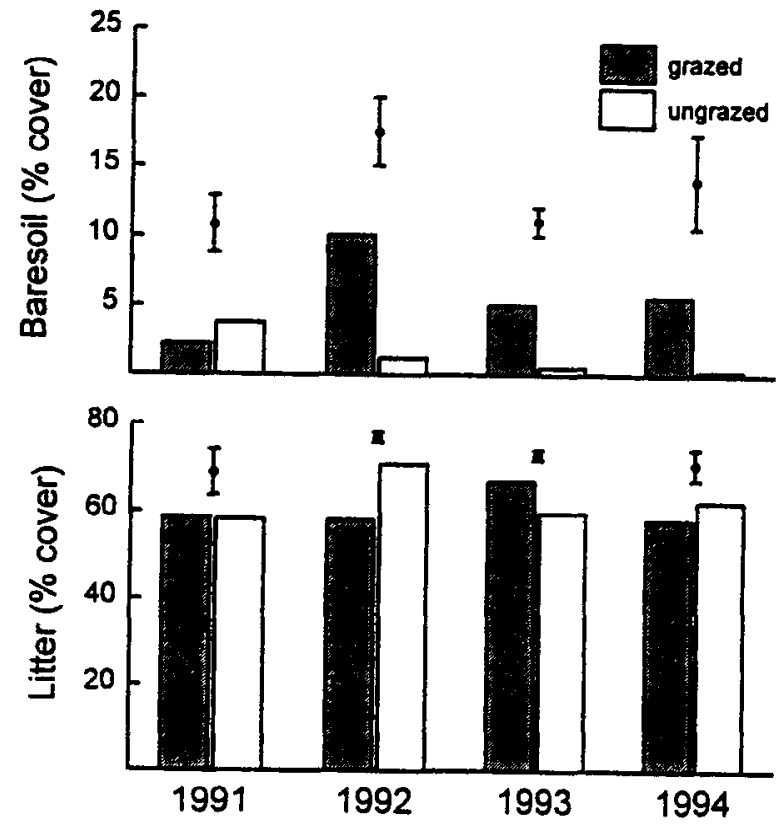

Fig. 3. Percent cover of bare soil and litter from 1991-1994 in grazed and ungrazed areas. Error bars represent \pm 1 S.E. 


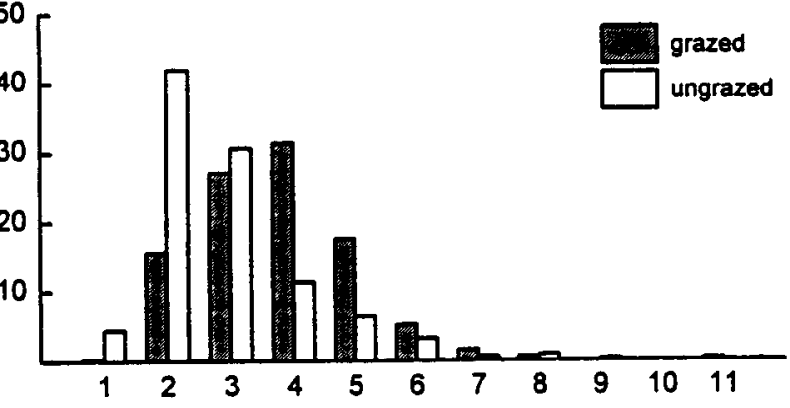

Age

Fig. 4. Age class distribution of spotted knapweed plants excavated from grazed and ungrazed areas in 1994 after 3 years of sheep grazing.

stems (vegetative and flowering) and flowering stems than ungrazed plants, although the magnitude of these differences varied among the 3 pastures (pasture by treatment interaction; stems, $P<0.001$; flowering stems, $P<0.003$ ). Grazed plants had lower stem (vegetative and flowering) and flowering stem densities than ungrazed plants. Basal areas of grazed spotted knapweed plants were twice as large as ungrazed plants.

While aging spotted knapweed plants, we observed that some of the taproots occasionally had necrotic tissue. Plants from grazed areas had a higher frequency of necrotic tissue than plants from ungrazed areas $(15.6 \%$ versus $7.6 \%$ S.E. $1.4 \%, \mathrm{P}<0.06)$.

Leaves and flower stems were shorter on grazed than ungrazed Idaho fescue plants (Table 2). Grazed plants tended to have more flowering stems, and greater flowering stem densities than ungrazed plants. Grazed and ungrazed Idaho fescue plants had similar basal areas.

\section{Discussion}

Response of a spotted knapweed infested Idaho fescue community was examined at 3 different ecological scales. At the community level, sheep grazing reduced spotted knapweed plant density, increased Kentucky bluegrass frequency, and minimally affected native species, Idaho fescue and arrowleaf balsamroot.

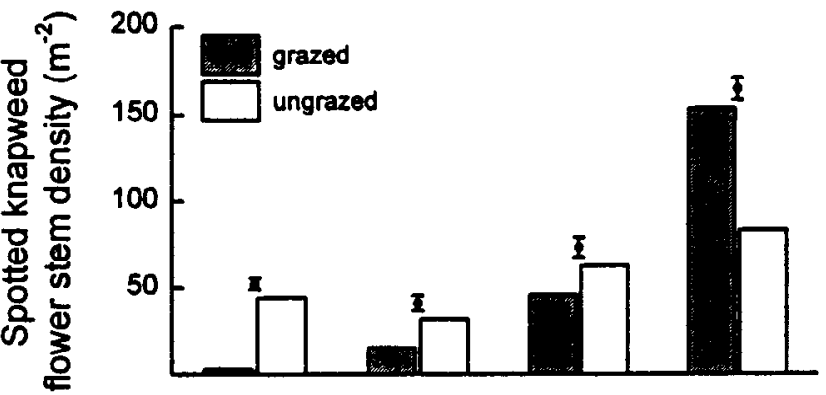

Fig. 5. Densities of spotted knapweed flower stems in 1991-1994. Densities in 1991-1993 were determined in early September after the last grazing period each summer. Densities in 1994 were determined in late July, 10.5 months after the last grazing period in early September 1993. Error bars represent \pm 1 S.E.

The rhizomatous Kentucky bluegrass often increases with livestock grazing. This could be a concern if it continued to increase with intensive sheep grazing of weed infested pastures.

At the population level, the reduced density of spotted knapweed seedlings with and without grazing could be attributed to a reduction of viable seed in the seed bank. Presence of only a few seedlings after 1991 in both treatments may have reflected the success of the seedhead fly (Urophora spp.) which was first observed on spotted knapweed flower heads at the site in 1992.

Grazing altered age class distribution of spotted knapweed plants. Apparently, sheep prefer younger, smaller, presumably more palatable spotted knapweed plants. Spotted knapweed stems on older plants are fibrous and tough (Kelsey and Mihalovich 1987). In addition, seasonal increases in cnicin, a bitter tasting sesquiterpene lactone contained in stems and especially leaves of spotted knapweed (Locken and Kelsey 1987), and the high fiber content of stems may have deterred herbivory. Thus, by preferring younger age classes of spotted knapweed and by reducing viable seed production from older plants, the sheep were reducing recruitment into the population. This reduction may have been more pronounced had the study continued several more years.

The increase in necrosis of crowns of grazed spotted knapweed plants may affect water and nutrient uptake, and allocation of carbohydrates, potentially reducing a plant's ability to compete and shortening its life span. Crown and root rot complexes in alfalfa, which has a similar tap-root as spotted knapweed, affect cortical and vascular tissue, thereby reducing plant vigor, and increasing wilting and mortality (Leath 1990). Equipment associated with

Table 2. Response of spotted knapweed and Idaho fescue in June 1994 after 3 years of repeated sheep graxing. Each year, pastures were grazed for 5 to 7 days in mid June, 2 to 6 days in July, and 1 to 2 days in early September depending on available forage.

\begin{tabular}{|c|c|c|c|c|c|c|c|c|}
\hline & \multicolumn{3}{|c|}{ Spotted knapweed } & \multicolumn{4}{|c|}{ Idaho fescue } & \multirow[b]{2}{*}{ P-value } \\
\hline & grazed & ungrazed & SE & P-value & grazed & ungrazed & $\mathrm{SE}$ & \\
\hline leaf height $(\mathrm{cm})$ & 57.6 & 59.9 & 2.2 & 0.47 & 17.5 & 28.4 & 1.8 & 0.0001 \\
\hline flower stem height (cm) & $57.6^{1}$ & 59.9 & 2.2 & 0.47 & 51.6 & 61.9 & 1.6 & 0.0002 \\
\hline stems plant ${ }^{-1}$ & $5.0^{2}$ & 3.1 & 0.3 & 0.0002 & 30.6 & 31.6 & 3.3 & 0.84 \\
\hline flower stems plant ${ }^{-1}$ & 5.0 & 3.0 & 0.3 & 0.0001 & 1.0 & 0.5 & 0.3 & 0.14 \\
\hline stem density $\left(\mathrm{cm}^{-2}\right)$ & 1.1 & 1.3 & 0.03 & 0.0001 & 2.0 & 1.9 & 0.1 & 0.27 \\
\hline flower stem density $\left(\mathrm{cm}^{-2}\right)$ & 1.0 & 1.2 & 0.03 & 0.002 & 0.04 & 0.02 & 0.01 & 0.12 \\
\hline basal area $\left(\mathrm{cm}^{2}\right)$ & 8.2 & 4.0 & 0.50 & 0.0001 & 21.7 & 22.3 & 2.0 & 0.83 \\
\hline
\end{tabular}

${ }^{1}$ Spotted knapweed bolts in late June-early July. When it bolts, stem and flower stem heights are the same.

${ }^{2}$ Stems include vegetative and flowering stems. 
harvesting alfalfa has been implicated in wounding the crown of alfalfa plants, and thereby increasing the incidence of disease. Intensive grazing of spotted knapweed by sheep may also wound the crown of this plant.

The significant reduction in flowering stems at the end of the 1991 grazing season was not as pronounced following the 1992 and 1993 grazing seasons, indicating that sheep reduced their use of flower stems, or that there was compensatory increase in number of flowering stems by spotted knapweed in grazed areas (Paige and Whitham 1987), or both. The compensatory increase in flower stem production in 1994 indicates that using sheep as a sole means to control this plant would require a long-term commitment. Sheep will not eliminate the plant from the community given its long-term seed viability (Davis et al. 1993) and compensatory increase in flower stem numbers, however, sheep have the potential to reduce its dominance. The compensatory increase in flower stem numbers by Idaho fescue plants in 1994 indicated either a response to stress, i.e. plants increase reproductive effort as a last chance to continue their population, or an increase in belowground resources because of the reduced competitiveness of other species (Mueggler 1970), presumably spotted knapweed.

At the individual plant level, previously grazed Idaho fescue plants had shorter leaves than ungrazed plants which could indicate reduced vigor and competitiveness. Mueggler (1970) initially suggested that the number of flower stems was a good indicator of the vigor of Idaho fescue, but later suggested that maximum leaf length was the most appropriate indicator (Mueggler 1975). Several plant species become more prostrate with longterm grazing (e.g. Detling and Painter 1983) which may be an evolutionary response to reduce herbivory (Jaindl et al. 1995). Although leaf heights of Idaho fescue plants in grazed and ungrazed areas differed, basal areas were similar. In a related study at this site, above- and belowground biomass were less for grazed Idaho fescue plants than ungrazed plants (Olson and Wallander 1997). Given that size and biomass are positively correlated, shorter leaves on previously grazed Idaho fescue plants in this study agrees with reduced biomass in previously grazed plants from the other study.

\section{Conclusion}

Sheep will graze spotted knapweed. Repeated sheep grazing initially reduces current flower stem production, although flower stem production may increase in subsequent years if grazing is not continued. By controlling the time of grazing and by repeatedly grazing spotted knapweed while associated grasses were going dormant, the age class distribution of spotted knapweed was altered (i.e. there were fewer, albeit older and larger plants), and its reproduction was reduced with minimal impact on the associated grasses. Sheep grazing may slow the rate of increase of spotted knapweed in native plant communities.

\section{Literature Cited}

AOSA. 1970. Tetrazolium testing handbook for agricultural seeds. Contribution No. 29. Assoc. of Official Seed Analysts.

Cox, J.W. 1989. Observations, experiments and suggestions for research on the sheep-spotted knapweed relationship, p. 79-82. In: P.K. Fay and J.R. Lacey (eds.), Proc. Knapweed Symposium. Montana State Univ., Bozeman, Mont.
Davis, E.S., P.K. Fay, T.K. Chicoine, and C.A. Lacey. 1993. Persistence of spotted knapweed (Centaurea maculosa) seed in soil. Weed Sci. 41:57-61.

Detling, J.K. and E.L Painter. 1983. Defoliation responses of western wheatgrass populations with diverse histories of prairie dog grazing. Oecologia 57:65-71.

Gill, J.L. 1981. Evolution of statistical design and analysis of experiments. J. Dairy Sci. 64:1494-1519.

Jaindl, R.G., P. Doescher, R.F. Miller, and L.E. Eddleman. 1995. Persistence of Idaho fescue on degraded rangelands: Adaptation to defoliation or tolerance. J. Range Manage. 47:54-59.

Kelsey, R.G. and L.J. Locken. 1987. Phytotoxic properties of cnicin, a sesquiterpene lactone from Centaurea maculosa (spotted knapweed). J. Chem. Ecol. 13:19-33.

Kelsey, R.G. and R.D. Mihalovich. 1987. Nutrient composition of spotted knapweed (Centaurea maculosa). J. Range Manage. 40:277-281.

Kennett, G.A., J.R. Lacey, C.A. Butt, K.M. Olson-Rutz, and M.R. Haferkamp. 1992. Effects of defoliation, shading and competition on spotted knapweed and bluebunch wheatgrass. J. Range Manage. 45:363-369.

Lacey, C.A., J.R. Lacey, P.K. Fay, J.M. Story, and D.L. Zamora. 1992. Controlling knapweed on Montana rangeland. Mont. State Univ. Ext. Ser. Circ. 311 , Bozeman, Mont.

Lacey, J.R., K.M. Olson-Rutz, M.R. Haferkamp, and G.A. Kennett. 1994. Effects of defoliation and competition on total nonstructural carbohydrates of spotted knapweed. J. Range Manage. 47:481-484.

Leath, K.T. 1990. Crown and root rot complexes, p. 43-44. In: D.L. Stuteville and D.C. Erwin (eds.), Compendium of alfalfa diseases. Second Ed. The Amer. Phytopathological Soc..

Locken, L.J. and R.G. Kelsey. 1989. Cnicin concentrations in Centaurea maculosa, spotted knapweed. Biochem. Syst. Ecol. 15:313-320.

Mueggler, W.F. 1970. Influence of competition on the response of Idaho fescue to clipping. USDA For. Serv. Res. Pap INT-73.

Mueggler, W.F. 1975. Rate and pattern of vigor recovery in Idaho fescue and bluebunch wheatgrass. J. Range Manage. 28:198-204.

Olson, B.E. and R.T. Wallander. 1997. Biomass and carbohydrates of spotted knapweed and Idaho fescue after repeated grazing. J. Range Manage. 50:409-412.

Paige, K.N. and T.G. Whitham. 1987. Overcompensation in response to mammalian herbivory: The advantage of being eaten. Amer. Nat. 129:408-416.

Pechanac, J.F. 1936. Comments on the stem-count method of determining the percentage utilization on range. Ecology 17:329-331.

SAS. 1988. Statistical analysis system. SAS Institute Inc. Raleigh, N.C.

Tyser, R.W. and C.H. Key. 1988. Spotted knapweed in natural area fescue grasslands: An ecological assessment. Northwest Sci. 62:981-987.

U.S.D.A. 1995. Natural Resources Conservation Service. Gallatin County Soil Survey. Bozeman, Mont.

Watson, A.K. and A.J. Renny. 1974. The biology of Canadian weeds Centaurea diffusa and C. maculosa. Can. J. Plant Sci. 54:687-701. 